\title{
PENERAPAN ANALISIS KONTEN PADA PERAN WIRAUSAHAWAN SOSIAL MUDA DALAM UPAYA PENGEMBANGAN PARIWISATA HALAL YANG BERKELANJUTAN
}

\author{
Baiq Nanda Aulia ${ }^{1}$, Baiq Handayani Rinuastuti ${ }^{2}$, Akhmad Saufi ${ }^{3}$ \\ 1 Program Studi Magister Manajemen Fakultas Ekonomi dan Bisnis Unram, \\ baiqnandaa@gmail.com \\ 2Fakultas Ekonomi dan Bisnis, Universitas Mataram, \\ hrinuastuti@yahoo.com \\ 35akultasEkonomi dan Bisnis, Universitas Mataram. \\ akh.saufi72@gmail.com
}

\section{ARTICLE INFO}

\section{Keywords :}

Content analysis; young social entrepreneurs; halal tourism; sustainable tourism.

\section{Kata Kunci :}

Analisis konten; wirausahawan sosial muda; pariwisata halal; pariwisata berkelanjutan.

How to cite :

Aulia, Baiq Nanda., Rinuastuti, Baiq Handayani., Saufi, Akhmad., (2020). Analisis Konten Penerapan Analisis Konten Pada Peran Wirausahawan Sosial Muda Dalam Upaya Pengembangan Pariwisata Halal Yang Berkelanjutan, 9 (4a) JMM UNRAM, 27-38

DOI :

http://dx.doi.org/10.29303/jmm.v9i4a.604

$\begin{array}{ll}\text { Dikumpulkan } & : 24 \text { November } 2020 \\ \text { Direvisi } & : 22 \text { Desember } 2020 \\ \text { Dipublikasi } & : 29 \text { Desember } 2020\end{array}$

jmm.unram.ac.id

\begin{abstract}
This study aims to see how to conduct an analysis in a phenomenon which is to find the role of young social entrepreneurs in the development of sustainable tourism efforts on the Lombok Island with a content analysis approach. Data collection was carried out through observation, interviews and documentation on young social entrepreneurs on the Lombok Island. The results of the study obtained 3 categories, 8 themes and 16 topics through open and axial coding processes. This study reveals 3 main roles of social entrepreneurs, namely as a stimulator, resource sustainability protector and quality assurance of sustainable halal tourism. This study provides a reference for scientific development in qualitative research methods and a gap for future research.
\end{abstract}

Penelitian ini bertujuan untuk mengetahui bagaimana melakukan analisis dalam sebuah fenomena yakni untuk menemukan peran wirausahawan sosial muda dalam upaya pengembangan pariwisata halal yang berkelanjutan di Pulau Lombok dengan pendekatan analisis konten. Pengumpulan data dilakukan melalui observasi, wawancara dan dokumentasi pada wirausahawan sosial muda di Pulau Lombok. Hasil penelitian ini mendapatkan 3 kategori, 8 tema dan 16 topik melalui proses open dan axial coding. Penelitian ini mengungkapkan 3 peran utama wirausahawan sosial 


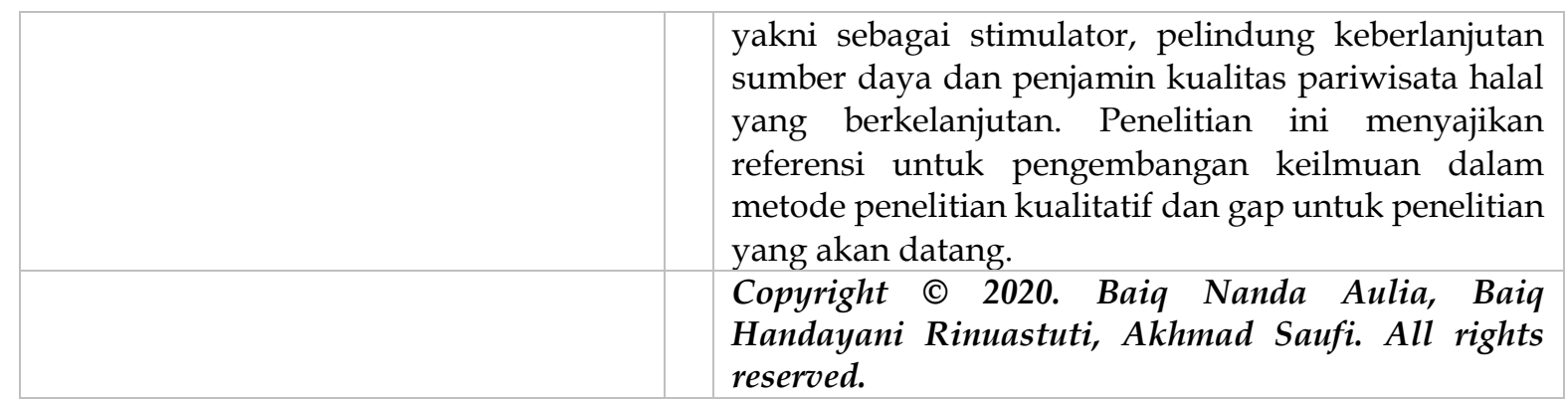

\section{PENDAHULUAN}

Pulau Lombok merupakan salah satu pulau di Indonesia yang terkenal dengan daya tarik alamnya. Beberapa atraksi wisata yang bisa di temukan di Pulau Lombok diantaranya adalah wisata pantai, keindahan bawah laut, pendakian gunung dan wisata sejarah. Perkembangan pariwisata NTB menunjukkan angka yang signifikan sampai sebelum bencana gempa bumi yang menimpa Pulau Lombok pada tahun 2018. Kunjungan wisatawan NTB mengalami peningkatan sebesar 61\% dari tahun 2013 hingga 2017. Peningkatan kunjungan wisatawan tertinggi berturut-turut pada tahun 2016 wisatawan dan 2015 sejalan dengan penobatan NTB sebagai pemenang penghargaan pariwisata halal pada World Halal Tourism Award tahun 2015 dan 2016. Industri halal, pada kenyataannya, membahas beberapa dari tujuh belas tujuan pembangunan berkelanjutan (SDGs) dan dapat memiliki kontribusi yang signifikan terhadap keberlanjutan (Azam et al., 2019). Alisjahbana (2017) menyatakan bahwa kemiskinan dan lingkungan hidup masih menjadi tantangan terbesar dalam proses pencapaian SDGs Provinsi Nusa Tenggara Barat. Upaya pengentasan masalah kemiskinan dan lingkungan hidup di NTB mampu diatasi dengan pengembangan potensi besar perekonomian daerah yakni pariwisata dan kewirausahaan sosial (Wibowo \& Nulhaqim, 2015). Besarnya manfaat kewirausahaan sosial untuk menuntaskan masalahmasalah yang ada di masyarakat menuntut peran para pemuda NTB untuk ikut andil sebagai wirausahawan sosial. Kewirausahaan sosial dapat membantu merangsang ekonomi dan dapat memberikan solusi terkait masalah sosial yang tidak dapat diatasi oleh pemerintah.

Penelitian Sloan (2014), Singh (2016) dan de Lange \& Dodds (2017) menyatakan usaha sosial yang skala usahanya masih kecil mampu merangsang industri yang lebih besar untuk menerapkan praktik keberlanjutan sehingga pariwisata berkelanjutan mulai menjadi tren pariwisata baru. Penelitian lain oleh Dahles et al (2019) dan Castellani et al (2020) menjelaskan bahwa model bisnis kewirausahaan sosial pariwisata dimana masyarakat lokal, wisatawan dan stakeholder terlibat di dalamnya memberikan manfaat lebih banyak terhadap masyarakat. Selain menjadi penerima manfaat, masyarakat lokal dipersiapkan sebagai peserta dan mitra dalam usaha bisnis berbasis pariwisata, dan didorong untuk terlibat dalam kewirausahaan dan kepemilikan bisnis serta berperan aktif dalam perencanaan pariwisata. Lebih jauh lagi, Ningdong \& Mingqing (2017) dan Leu et al (2018) juga menjelaskan bahwa wirausahawan sosial pariwisata mampu berkontribusi dalam sektor budaya, sosial, psikologi hingga politik.

Penelitian ini bertujuan untuk menemukan peran wirausahawan sosial muda dalam upaya pengembangan pariwisata halal yang berkelanjutan di Pulau Lombok melalui pendekatan analisis konten. Kewirausahaan sosial sudah menjadi tren kewirausahaan di kalangan pemuda Indonesia. Mereka memiliki jiwa kewirausahaan, tidak hanya berdasar pada kemampuan mereka mendirikan sebuah bisnis dan memperoleh keuntungan untuk 
dirinya sendiri tetapi mampu menjalankan usahanya untuk kepentingan peningkatan keadaan sosial dan ekonomi masyarakat (Puspitasari, 2018).

\section{KAJIAN LITERATUR}

\subsection{Analisis Konten}

Analisis konten didefinisikan sebagai sekumpulan prosedur untuk mempelajari isi teks tertulis atau ditranskrip yang memungkinkan peneliti untuk memasukkan sejumlah besar informasi tekstual dan secara sistematis mengidentifikasi sifat-sifatnya seperti frekuensi kata kunci yang paling sering digunakan (Klenke, 2008). Menurut Krippendorff (2012), analisis konten memungkinkan peneliti membuat kesimpulan yang dapat direplikasi dan valid dari data ke konteksnya. Data tekstual dapat dalam bentuk verbal, cetak, atau elektronik dan dapat diperoleh dari tanggapan naratif, pertanyaan survei terbuka, wawancara, kelompok fokus, observasi, atau media cetak seperti artikel, buku, atau manual (Kondracki \& Wellman, 2002). Tujuan menggunakan analisis konten sebagai metode penelitian adalah untuk memberikan wawasan baru dan meningkatkan pemahaman tentang fenomena tertentu, dan untuk mendapatkan deskripsi fenomena yang lebih luas dan lebih ringkas, serta untuk mendeskripsikan dan mengukur suatu fenomena (Moldavska \& Welo, 2017). Analisis konten sebagai metode mencakup strategi penelitian kuantitatif dan kualitatif. Analisis kuantitatif memberikan hasil berupa frekuensi, biasanya menjawab pertanyaan 'berapa'. Analisis kualitatif menyajikan data dalam bentuk kategori, memungkinkan interpretasi teks (Bengtsson, 2016). Analisis konten kualitatif mencoba mengatasi kekurangan analisis kuantitatif seperti memberikan jawaban tentang bagaimana kategori diturunkan dengan menerapkan pendekatan sistematis yang dipandu teori untuk analisis teks.

Pendekatan pada analisis konten dapat dibedakan menjadi dua yaitu analisis induktif dan deduktif (Moretti et al., 2011). Pendekatan induktif, yaitu proses perpindahan dari yang spesifik ke umum, berarti bahwa contoh-contoh pidato tertentu diamati dan kemudian digabungkan menjadi pernyataan yang lebih besar. Penelitian ini digunakan jika tidak ada penelitian sebelumnya yang membahas fenomena tersebut. Pendekatan deduktif, di sisi lain, bergerak dari yang umum ke yang spesifik (Burns \& Grove, 2005). Analisis konten deduktif digunakan untuk menguji ulang data yang ada dalam konteks baru, menguji kategori, konsep, model, atau hipotesis. Ini biasanya didasarkan pada pekerjaan sebelumnya seperti teori, model, peta pikiran, dan tinjauan literatur (Hsieh \& Shannon, 2005). Salah satu tantangan analisis konten adalah kurangnya resep atau standar umum untuk pelaksanaannya. Oleh karena itu, kualitas analisis konten telah dibahas secara luas oleh para peneliti. Dalam kasus analisis konten, istilah seperti validitas, reliabilitas, dan kepercayaan telah digunakan untuk menangani kualitas penelitian (Elo et al., 2014).

\subsection{Konsep Kewirausahaan Sosial}

Konsep kewirausahaan sosial merupakan perluasan dari konsep dasar kewirausahaan yang secara historis telah diakui sebagai pengungkit ekonomi, terutama dalam menyelesaikan masalah sosial (Noruzi et al 2010; Patra and Nath 2014). Wibowo \& Nulhaqim (2015) mendefinisikan kewirausahaan sosial sebagai sebuah gerakan dengan misi sosial, yang diusahakan dengan upaya-upaya menemukan peluang dan mengolahnya dengan inovasi dan proses belajar yang tiada henti serta kesiapan untuk bertindak tanpa dukungan sumber daya yang memadai. Alford dalam Sloan et al (2014) mendefinisikan kewirausahaan sebagai sebuah proses yang menciptakan solusi inovatif untuk masalah sosial langsung dan memobilisasi ide, kapasitas, sumber daya, dan pengaturan sosial yang jmm.unram.ac.id 
diperlukan untuk transformasi sosial berkelanjutan. Nilai yang dituju oleh sociopreneurship adalah nilai sosial sebab kewirausahaan sosial sangat menekankan bagaimana menciptakan ide atau gagasan yang bersifat inovatif dalam rangka menyelesaikan permasalahan sosial. Hulgard (2010) mejelaskan empat elemen utama dalam kewirausahaan sosial yakni antara lain:

- Social Value yakni adanya manfaat sosial yang nyata bagi masyarakat dan lingkungan sekitar.

- Civil Society yakni bentuk inisiatif dan partisipasi masyarakat sipil dengan mengoptimalkan modal sosial yang ada di masyarakat.

- Innovation yakni inovasi yang dilakukan dalam pemecahan masalah dengan melihat kearifan lokal masyarakat.

- Economic Activity yakni keseimbangan antara aktivitas sosial dan aktivitas bisnis untuk menjamin kemandirian dan keberlanjutan misi sosial organisasi.

Istilah socio entrepreneur mulai menjadi tren anak muda (Suyatna \& Hurhasanah, 2017). Terbukti beberapa wirausahawan sosial muda telah berhasil berkontribusi dalam penyelesaian masalah sosial ekonomi masyarakat. Definisi dari wirausahawan sosial muda masih menjadi bias. Apabila mengacu pada definisi Ashoka tentang kewirausahaan sosial yakni sebagai "catalysts of system wide social change" akan mengecualikan sebagian besar orang-orang muda di bawah usia 18 tahun karena sebagian besar inisiatif yang dipimpin oleh kaum muda tidak membuat perubahan besar. Menurut UNICEF (2007), wirausahawan sosial muda adalah mereka yang memprakarsai perubahan dalam masyarakat dan mengambil inisiatif untuk meningkatkan kehidupan mereka sendiri dan masyarakat dengan meluncurkan desain usaha mereka sendiri di usia muda. Menurut ELYSE (2016), wirausahawan sosial muda adalah individu yang bersemangat dengan visi untuk menyelesaikan kebutuhan yang tidak terpenuhi dan mengubah dunia tempat mereka tinggal dan melewati setiap tantangan yang disebabkan oleh usia mereka yang muda.

\subsection{Pariwisata Halal dan Berkelanjutan}

Islam memiliki dampak yang signifikan pada sikap dan perilaku kehidupan seharihari umat Islam, termasuk pariwisata, yaitu pada keputusan mengenai kegiatan yang akan dilakukan untuk mengisi waktu luang saat bepergian namun tetap menghormati ajaran dan kewajiban yang ditetapkan dalam hukum Syariah. Maka tidak heran apabila berbagai macam desain pelayanan pariwisata disediakan untuk para wisatawan Muslim yang mengikuti ajaran Islam (Vargas-Sánchez \& Moral, 2019). Battour \& Ismail (2015) menyatakan bahwa sebagian besar dari definisi-definisi tersebut secara komprehensif belum mempertimbangkan hukum Islam (syariah), target pelanggan (yaitu Muslim atau nonMuslim), lokasi kegiatan (yaitu negara Muslim vs non-Muslim), produk dan layanan yang ditawarkan (yaitu makanan, fasilitas) dan tujuan perjalanan. Maka dari itu mereka menyimpulkan bahwa pariwisata halal adalah setiap objek atau tindakan pariwisata yang diizinkan menurut ajaran Islam untuk digunakan atau dilibatkan oleh umat Islam dalam industri pariwisata. Konsep halal juga mengadopsi pembangunan berkelanjutan yang menjadi perhatian dunia yang tertanam di setiap bidang kehidupan manusia termasuk aspek ekonomi, lingkungan, dan sosial. Pembangunan pariwisata berkelanjutan merupakan sebuah proses dan sistem pengembangan pariwisata yang bisa menjamin keberlangsungan atau keberadaan sumber daya alam dan kehidupan sosial-budaya serta memberikan manfaat ekonomi kepada generasi sekarang hingga generasi yang akan datang guna memberantas atau mengentasakan kemiskinan (WTO, 2004). 
Mengadopsi konsep halal dalam sebuah bisnis atau memilih industri halal sebagai pilihan bisnis sebenarnya memiliki kontribusi terhadap keberlanjutan. Bagi seorang wirausahawan Muslim, hadiah spiritual adalah pencapaian tambahan. Oleh karena itu mempromosikan konsep industri halal yang berkelanjutan di antara semua ekonomi untuk meningkatkan efisiensi pencapaian SDGs sangat penting. Pariwisata halal, sebagai mode pariwisata yang bertanggung jawab, menghentikan pemborosan, mendorong kebersihan, dan memungkinkan wisatawan Muslim dan masyarakat lokal untuk hidup menurut aturan Islam memastikan kegiatan pariwisata berkelanjutan. Pariwisata halal berkontribusi pada keberlanjutan dengan pendekatan yang ramah lingkungan dan menawarkan potensi ekonomi yang besar masyarakat sekitar. Pariwisata dan pembangunan berkelanjutan merupakan dua instrument yang tidak dapat dipisahkan karena hubungan keduanya yang saling menguntungkan. Penerimaan dari sektor pariwisata dapat berkontribusi dalam upaya pembangunan keberlanjutan dan pembangunan berkelanjutan memberikan dampak positif bagi kemajuan sektor pariwisata (Subarkah et al., 2019).

\subsection{Peran Kewirausahaan Sosial dalam Pengembangan Pariwisata Berkelanjutan}

Penelitian yang dilakukan oleh de Lange \& Dodds (2017) menjelaskan bahwa hubungan umum di antara kewirausahaan sosial dan pariwisata adalah inovasi dan pertumbuhan. Kewirausahaan yang fokus pada penyelesaian masalah sosial dan lingkungan dengan menawarkan barang dan jasa terkait dapat merangsang industri yang lebih besar untuk berkelanjutan secara luas. Pariwisata berkelanjutan dapat menjadi lebih dari sekadar ceruk. Kewirausahaan sosial menumbuhkan keberlajutan pariwisata melalui penciptaaan pilihan lain (alternative) bagi pengunjung dan menciptakan sedikit tekanan bagi perusahaan yang sudah ada sehingga keberlanjutan akan terus tumbuh besar.

Temuan kunci pada penelitian Mottiar et al (2018) adalah bahwa wirausahawan sosial memainkan peran penting dalam pengembangan destinasi pedesaan. Mereka merupakan kekuatan yang signifikan dalam mengidentifikasi potensi pariwisata di destinasi pedesaan (oportunis), mengkatalisasi visi kolektif, dan beroperasi sebagai arsitek jaringan untuk mencapai tujuan sosial. Temuan tersebut menunjukkan bahwa wirausahawan sosial pedesaan cenderung menjadi fitur dari banyak destinasi di seluruh dunia. Oleh karena itu, wirausahawan sosial harus menjadi bagian dari wacana destinasi untuk lebih memahami tujuan sosial dari transisi masyarakat dari pertanian ke ekonomi pariwisata.

Valdivia (2018) pada hasil penelitiannya menjelaskan motivasi, karakteristik dan tujuan wirausahawan sosial muda membangun CBRT dan bagaimana wirausahawan sosial muda menjalankan perannya dalam masyarakat, konservasi alam, budaya dan tradisi, manjemen terhadap persaingan dan pembentukan pemimpin-pemimpin baru. Dalam masyarakat, wirausahawan sosial muda berfungsi untuk meyakinkan penduduk akan kemampuan diri mereka sendiri terhadap pengembangan CBRT. Wirausahawan sosial juga bertanggungjawab untuk menjaga alam, budaya dan tradisi dari kerusakan aktivitas pariwisata. Selain itu, mereka bertugas sebagai manajer dalam CBRT untuk menangani persaingan dan membentuk pemimpin baru sebagai bagian dari proses regenerasi.

\section{METODE PENELITIAN}

Jenis penelitian yang digunakan adalah penelitian kualitatif dengan pendekatan analisis konten. Hal ini bertujuan untuk memberikan wawasan baru dan meningkatkan pemahaman tentang peran wirausahawan sosial muda dalam pengembangan pariwisata halal yang berkelanjutan. Analisis konten kualitatif adalah analisis teks terpandu aturan yang sistematis yang mempertahankan beberapa kekuatan analisis konten kuantitatif dan jmm.unram.ac.id 
memperluasnya untuk mengadopsi berbagai prosedur kualitatif. Pada analisis konten terhadap 3 tahap pelaksanaan yakni tahap persiapan, organisasi, dan pelaporan hasil. Namun, prosedur bertahap yang disajikan di sini tidak boleh ditafsirkan sebagai preskriptif karena tidak ada aturan sistematis untuk mengumpulkan dan menganalisis data dengan mengingat bahwa fitur utama dari semua prosedur analisis konten adalah pengurangan banyak kata menjadi sejumlah kategori yang lebih kecil (Klenke, 2008).

\subsection{Perencanaan}

Perencanaan dimulai dengan menentukan informan yang sesuai dengan rumusan masalah sehingga temuan di lapangan bisa menjadi instrument dalam pengembangan penelitian. Penelitian ini menggunakan teknik purposive sampling dalam proses penentuan informan. Purposive sampling sangat sesuai dengan penelitian kualitatif karena peneliti tertarik pada informan yang memiliki pengetahuan terbaik tentang topik penelitian. Informan pada penelitian ini adalah wirausahawan sosial di Lombok dengan usia di atas 16 tahun dan memulai usahanya di bawah umur 30 tahun. Batas umur pada penelitian ini mengacu pada pengertian pemuda menurut Undang-Undang No. 40 tentang Kepemudaan Pasal 1 ayat 1 . Para informan tersebut dijelaskan pada tabel berikut:

Tabel 1 Informan Penelitian

\begin{tabular}{cll}
\multicolumn{2}{c}{ Nama Informan } & \multicolumn{1}{c}{ Nama Usaha Sosial } \\
\hline 1. & Andriawan Abdi & Sudut Lombok \\
\hline 2. & Kris Ayu Madina & Gumi Bamboo \\
\hline 3. & Azudinnur & Desa Wisata Sesaot \\
\hline 4. & Siti Aisyah & $\begin{array}{l}\text { Bank Sampah NTB Sejahtera dan Kawis Krisant } \\
\text { (Kampung Wisata Kreatif Sampah Terpadu) }\end{array}$ \\
\hline
\end{tabular}

\subsection{Pengumpulan Data}

Metode dokumentasi, observasi dan wawancara menjadi metode utama pengumpulan data, seperti yang direkomendasikan oleh Jennings (2011). Penelitian ini menggunakan dua jenis data yaitu data primer dan data sekunder. Data primer didapatkan dari observasi dan wawancara di lapangan sedangkan data sekunder didapatkan melalui catatan atau dokumentasi perusahaan, sosial media dan situs web perusahaan. Proses pengumpulan data dilaksanakan pada 2 Juli 2020 sampai 11 Juli 2020 dengan jumlah informan pada penelitian ini sebanyak 4 orang. Alat yang digunakan dalam proses pengumpulan data adalah smartphone, recorder, instrumen guiding question agar proses penggalian lebih terarah dan alat tulis untuk membuat catatan-catatan dalam proses penelitian.

Proses dokumentasi dilakukan dengan mengumpulkan dokumen-dokumen terkait wirausahawan sosial dan usaha sosialnya yang diungkapkan secara online melalui media sosial dan website mereka dan pengambilan foto di lokasi usaha. Observasi dilakukan dengan mengunjungi lokasi usaha sosial secara langsung. Peneliti memperhatikan cara kerja wirausahawan sosial secara langsung dan berhasil mengetahui lebih banyak tentang bagaimana fakta yang ada di lapangan tentang peran wirausahawan sosial dan tanggapan masyarakat terkait adanya usaha sosial tersebut. Selanjutnya, metode pengumpulan data utama pada penelitian ini adalah wawancara. Proses wawancara dilaksanakan melalui dua metode yaitu wawancara langsung dan wawancara daring. Pemilihan metode wawancara disesuaikan dengan kenyamanan informan mengingat keadaan pandemi COVID-19 yang tidak memungkinkan bertemu langsung dengan informan. Wawancara secara satu per satu 
dilakukan dengan tujuan mendapatkan eksplorasi mendalam tentang pemikiran, perasaan, dan pemahaman mereka. Durasi wawancara berkisar antara 120-150 menit.

\subsection{Analisis Data}

Penelitian ini menggunakan open coding dan axial coding dalam proses analisinya. Open coding dirancang untuk mengekspresikan data dalam bentuk kode awal. Sebuah teks dapat diberi kode baris demi baris, kalimat demi kalimat, atau paragraf demi paragraf, atau kode dapat dihubungkan ke seluruh teks. Axial coding mengikuti open coding sebagai langkah selanjutnya untuk menyempurnakan dan membedakan kategori yang dihasilkan dari open coding. Dari sekian banyak kategori yang bermula dari open coding, dipilihlah yang tampaknya paling menjanjikan untuk dielaborasi lebih lanjut (Klenke, 2008). Untuk lebih spesifik dengan pengkodean, peneliti mengikuti proses yang disarankan oleh Löfgren (2013) dalam Valdivia (2018), yang mempertimbangkan langkah-langkah berikut: (1) Transkrip wawancara: semua transkrip dibaca dan catatan dibuat pada kesan pertama. (2) Pengkodean: kata-kata, frasa, dan kalimat penting diberi label untuk memulai proses pengkodean. Pengkodean didasarkan pada pernyataan yang berulang-ulang, fakta-fakta yang mengejutkan peneliti atau fakta-fakta yang secara eksplisit dinyatakan penting oleh peserta. (3) Kategorisasi: peneliti memutuskan kode mana yang paling penting, dan membuat kategori atau tema dengan menyatukan beberapa kode. (4) Konseptualisasi data: peneliti menganalisis kategori mana yang paling relevan dan bagaimana mereka terhubung satu sama lain. (5) Hasil: Kategori dan keterkaitannya merupakan hasil utama dari penelitian ini.

\subsection{Triangulasi Data}

Triangulasi merupakan teknik pemeriksaan keabsahan data yang memanfaatkan sesuatu yang lain. Menurut Moleong (2011), uji keabsahan data dalam penelitian kualitatif yang digunakan untuk mencapai standar memiliki empat kriteria yakni sebagai berikut:

1. Kepercayaan (credibility): Pemenuhan kriteria ini dilakukan dengan pengecekan kesesuaian antara hasil pengamatan dan realitas di lapangan melalui proses konfirmasi oleh stakeholder. Pada proses observasi langsung di lokasi usaha sosial, beberapa stakeholder yang terlibat dalam usaha sosial bisa ditemui dan bersedia memberikan beberapa konfirmasi terkait fakta di lapangan.

2. Keteralihan (transferability): Untuk membangun keteralihan, penulisan laporan hasil penelitian dilakukan seteliti dan secermat mungkin terkait fokus penelitian. Laporan hasil penelitian ini ditulis dengan secara rinci, jelas, sistematis dan dapat dipercaya sehingga hasil penelitian ini mudah dipahami dan diterapkan oleh pembaca.

3. Kebergantungan (dependability): Untuk menghindari kesalahan dalam memformulasikan hasil penelitian, dilakukan konsultasi dengan berbagai pihak untuk ikut memeriksa proses penelitian yang dilakukan peneliti, agar temuan peneliti dapat dipertahankan dan dapat dipertanggungjawabkan secara ilmiah. Pihak yang ikut memeriksa adalah dosen pembimbing pada penelitian ini.

4. Kepastian (confirmability): Kriteria ini ikut diperiksa oleh dosen pembimbing penelitian ini, sama seperti pada kriteria sebelumnya. Konfirmabilitas dalam penelitian dilakukan bersamaan dengan dependabilitas. Perbedaannya terletak pada orientasi penilaian. Konfirmabilitas digunakan untuk menilai hasil penelitian. Sedangkan dependabilitas digunakan untuk menilai proses penelitian, mulai mengumpulkan data sampai pada bentuk laporan yang terstruktur dengan baik. 


\section{HASIL DAN PEMBAHASAN}

Tujuan dari analisis ini adalah untuk mengidentifikasi peran wirausahawan sosial muda dalam pembangunan pariwisata halal yang berkelanjutan di Pulau Lombok. Penelitian ini menggunakan tabel coding untuk membantu mulai tahap pengkodean hingga tahap penarikan kesimpulan. Kode diurutkan ke dalam kategori berdasarkan bagaimana kode yang berbeda terkait dan ditautkan (Patton, 2002). Tujuan dasar dalam proses pengkodean adalah untuk mengatur teks yang besar menjadi konten yang jauh lebih sedikit kategori, yaitu reduksi data. Saat analisis berlanjut, kode tambahan adalah dikembangkan, dan skema pengkodean awal direvisi dan disempurnakan. Kategori mungkin didefinisikan berdasarkan pertanyaan penelitian dan/atau teori dan konstruksi yang mendasari. Sebagai contoh, pada artikel ini, menjaga kelestarian alam, kelestarian budaya dan mengembangkan kualitas sumber daya manusia ditetapkan sebagai kategori yang terbentuk dari sejumlah sub-kategori dan kode. Kemudiam kategori yang saling berhubungan tersebut dikelompokkan lagi menjadi tema besar. Tabel coding ini akan mengklasifikasikan hasil dari tahap pengumpulan data kedalam beberapa bagian meliputi tema, kategori dan sub kategori. Berdasarkan hasil coding tersebut, dihasilkan 3 kategori, 8 tema dan 16 topik yang dapat dilihat pada tabel 2 sebagai berikut:

Tabel 2 Contoh Hasil Kodifikasi

\begin{tabular}{|c|c|c|c|}
\hline Kategori & Tema & Sub-tema & Frekuensi \\
\hline \multirow{7}{*}{ Stimulator } & \multirow{3}{*}{$\begin{array}{l}\text { 1. Mendirikan Usaha } \\
\text { Sosial }\end{array}$} & 1. Menemukan Motivasi Diri & 9 \\
\hline & & $\begin{array}{l}\text { 2. Mengidentifikasi Peluang } \\
\text { Bisnis }\end{array}$ & 10 \\
\hline & & $\begin{array}{l}\text { 3. Menciptakan Produk yang } \\
\text { Inovatif }\end{array}$ & 5 \\
\hline & \multirow[b]{2}{*}{$\begin{array}{l}\text { Meningkatkan Kualitas } \\
\text { Hidup }\end{array}$} & 4. Membangun Modal Sosial & 6 \\
\hline & & $\begin{array}{l}\text { 5. Meningkatkan Sosial-Ekonomi } \\
\text { Masyarakat }\end{array}$ & 14 \\
\hline & \multirow{2}{*}{$\begin{array}{l}\text { 3. Meningkatkan } \\
\text { Partisipasi }\end{array}$} & $\begin{array}{l}\text { 6. Merubah Sikap dan Perilaku } \\
\text { Masyarakat }\end{array}$ & 6 \\
\hline & & $\begin{array}{l}\text { 7. Mengkampanyekan Pariwisata } \\
\text { Halal yang Berkelanjutan }\end{array}$ & 6 \\
\hline \multirow{5}{*}{$\begin{array}{l}\text { Pelindung } \\
\text { Keberlanjutan } \\
\text { Sumber Daya }\end{array}$} & \multirow{2}{*}{$\begin{array}{l}\text { 4. Menjaga Kelestarian } \\
\text { Lingkungan }\end{array}$} & $\begin{array}{l}\text { 8. Meningkatkan Kesadaran } \\
\text { terhadap Lingkungan }\end{array}$ & 7 \\
\hline & & $\begin{array}{l}\text { 9. Melakukan Konservasi } \\
\text { Lingkungan }\end{array}$ & 13 \\
\hline & $\begin{array}{ll}\text { 5. Menjaga Kelestarian } \\
\text { Budaya }\end{array}$ & $\begin{array}{l}\text { 10. Menjaga Budaya Asli } \\
\text { Masyarakat }\end{array}$ & 5 \\
\hline & \multirow{2}{*}{$\begin{array}{l}\text { 6. Mengembangkan } \\
\text { Kualitas SDM }\end{array}$} & $\begin{array}{l}\text { 11. Memberikan Edukasi dan } \\
\text { Pelatihan }\end{array}$ & 7 \\
\hline & & $\begin{array}{l}\text { 12. Mempersiapkan Generasi } \\
\text { Penerus }\end{array}$ & 6 \\
\hline \multirow{4}{*}{$\begin{array}{l}\text { Penjamin } \\
\text { Kualitas }\end{array}$} & \multirow[t]{2}{*}{ 7. Menjalin Kerjasama } & $\begin{array}{l}\text { 13. Menciptakan Efisiensi } \\
\text { Operasional }\end{array}$ & 4 \\
\hline & & 14. Berbagi Pengetahuan & 8 \\
\hline & \multirow{2}{*}{$\begin{array}{ll}\text { 8. Menciptakan Kepuasan } \\
\text { Wisatawan }\end{array}$} & 15. Mengevaluasi Produk/Jasa & 15 \\
\hline & & 16. Menjaga Kualitas Destinasi & 9 \\
\hline
\end{tabular}

Kategori pada hasil coding di atas menunjukkan 3 peran besar yang dijalankan wirausahawan sosial muda dalam pengembangan pariwisata halal yang berkelanjutan yakni 
wirausahawan sosial sebagai stimulator partisipasi masyarakat, pelindung keberlanjutan sumber daya dan penjamin kualitas dari pariwisata halal dan berkelanjutan.

Analisis konten merupakan analisis yang sangat mendalam karena setiap kata, kalimat hingga paragraf diinterpretasikan dengan sangat teliti. Makna-makna eksplisit yang disebutkan oleh informan dapat dengan mudah diketahui melalui metode analisis konten. Maka dari itu, peran wirausahawan sosial muda dalam upaya pengembangan pariwisata halal yang berkelanjutan di Pulau Lombok dapat dijelaskan secara detail dan sistematis. Hasil dari analisis ini juga didapat langsung dari data tanpa perlu memaksakan praduga perspektif teoritis seperti yang disebutkan oleh Moldavska \& Welo (2017).

Namun proses analisis konten pada penelitian ini terkandala oleh sedikitnya pengetahuan penelitian sehingga membutuhkan waktu yang sangat lama untuk akhirnya mendapatkan hasil analisis. Tahapan tersulit pada analisis konten adalah mengelompokkan kode yang sangat banyak ke dalam kategori yang sesuai. Saat berada pada keadaan tersebut, mempelajari dan memahami teori-teori dalam penelitian dengan lebih mendalam dan lebih banyak mencari referensi adalah hal yang dilakukan peneliti untuk mengatasi masalah yang ada saat proses analisis data. Selain itu, analisis konten mengharuskan untuk fokus pada pertanyaan penelitian dan teori yang digunakan sehingga proses analisis tidak melebar dan keluar dari fokus penelitian. Kuckartz (2014) menjelaskan bahwa pada analisis konten, semakin banyak berorientasi pada teori, semakin luas pengetahuan peneliti, semakin fokus pertanyaan penelitian, dan semakin spesifik hipotesis yang ada, maka semakin mudah untuk berpindah dari kode ke kategori.

\section{KESIMPULAN}

Analisis konten yang dilakukan menghasilkan 3 kategori, 8 tema dan 16 sub-tema yang saling berhubungan untuk menjawab pertanyaan penelitian. Tiga kategori tersebut menjelaskan 3 peran wirausahawan sosial muda dalam upaya pengembangan pariwisata halal yang berkelanjutan di Pulau Lombok yakni sebagai stimulator, penjaga keberlanjutan sumber daya dan penjamin kualitas pariwisata halal yang berkelanjutan. Penerapan analisis konten pada penelitian ini mampu memberikan hasil analisis yang sangat mendalam karena dilakukan dengan sangat detail dan penuh kehati-hatian dalam proses pengkodean. Maka dari itu, peneliti diharuskan untuk sangat memahami teori dan fokus penelitian pertanyaan untuk memudahkan proses analisis sehingga hasil analisis yang didapatkan dapat dipertanggungjawabkan.

\subsection{Implikasi Teoritis}

Hasil penelitian ini memperkuat saran Moldavska \& Welo (2017) tentang tujuan penggunaan analisis konten dimana penelitian ini mampu menjabarkan peran wirausahawan sosial muda dalam upaya pembangunan pariwisata halal yang berkelanjutan di Pulau Lombok secara detail, rinci dan ringkas sehingga mudah untuk dipahami. Penelitian ini juga mengimplementasikan kriteria-kriteria kepercayaan dalam penelitian kualitatif dalam setiap tahapan penelitian mulai tahap perencanaan hingga pelaporan hasil penelitian. Seluruh metode yang digunakan harus dikaji terlebih dahulu untuk memastikan apakah hal tersebut merupakan pilihan terbaik dan sudah sesuai dengan tujuan penelitian. Hal ini mengelaborasi penjelasan Elo et al (2014) tentang validitas, reliabilitas, dan kepercayaan yang digunakan untuk menangani kualitas penelitian. 


\subsection{Keterbatasan dan Saran Penelitian yang Akan Datang}

Artikel ini menjelaskan bagaimana menemukan peran wirausahawan sosial muda dalam upaya pengembangan pariwisata halal yang berkelanjutan yang berfokus pada studi kewirausahaan dan pariwisata melalui konten analisis. Metode analisis ini dapat digunakan pada fokus penelitian yang lebih luas lagi untuk menggali lebih dalam tentang teori maupun implementasi dalam studi kewirausahaan dan kepariwisataan. Selain itu, hasil penelitian ini menghasilkan banyak variabel-variabel untuk dilanjutkan dalam penelitian lanjutan dan menguji hubungan antar variabelnya.

\section{Acknowledgments}

Penelitian ini ditulis sebagai hasil dari kerjasama antara Kementrian Pemuda dan Olahraga Republik Indonesia dan Universitas Mataram.

\section{DAFTAR PUSTAKA}

Alisjahbana, Armida S. (2017). Percepatan Pencapaian SDGs: Belajar dari Provinsi NTB. Available at: sdgcenter.unpad.ac.id/percepatan-pencapaian-sdgs-belajar-dariprovinsi-ntb/ [Diakses pada 10 Juni 2019]

Azam, M. S. E., Abdullah, M. A., \& Razak, D. A. (2019). Halal Tourism: Definition, Justification, and Scopes Towards Sustainable Development. International Journal of Business, Economics and Law, 18 (3), 23-31.

Battour, M. and Ismail, M.N. (2015). Halal Tourism: Concepts, Practises, Challenges and Future. Tourism Management Perspectives, 19, 150-154.

Bengtsson, M. (2016). How to plan and perform a qualitative study using content analysis. NursingPlus Open, 2, 8-14.

Burns, N., \& Grove, S.K. (2005). The Practice of Nursing Research: Conduct, Critique \& Utilization. Elsevier Saunders, St Louis.

Castellani, P., Bonfanti, A., Canestrino, R., \& Magliocca, P. (2020). Dimensions and triggers of memorable tourism experiences: evidence from Italian social enterprises. The TQM Journal. Advance online publication: https://doi.org/10.1108/TQM-11-2019$\underline{0259}$.

Dahles, H., Khieng, S., Verver, M., \& Manders, I. (2020). Social entrepreneurship and tourism in Cambodia: advancing community engagement. Journal of Sustainable Tourism, 28(6), 816-833.

De Lange, D., Dodds, R. (2017). Increasing Sustainable Tourism Through Social Entrepreneurship. International Journal of Contemporary Hospitality Management.

Elo, S., Kääriäinen, M., Kanste, O., Pölkki, T., Utriainen, K., \& Kyngäs, H. (2014). Qualitative content analysis: A focus on trustworthiness. SAGE open, 4(1), 2158244014522633.

Etchart, N., \& Comolli, L. (2013). Social enterprise in emerging market countries: No free ride. Springer.

ELYSE. (2016). European Learning for Youth in Social Entrepreneurship Final Report 2016.

Haugh, H., Lyon, F., \& Doherty, B. (2018). Social Entrepreneurship: Entrepreneurship and Social Value Creation

Hulgard, L. (2010). Discourses of Social Entrepreneurship-Variations of The Same Theme. EMES European Research Network, 10 (1), 2-21.

Hsieh, H. F., \& Shannon, S. E. (2005). Three approaches to qualitative content analysis. Qualitative health research, 15(9), 1277-1288.

Jennings, G. (2011). Tourism Research (Vol. Second Edition). Australia: Wiley Australia Tourism Series. 
Klenke, K. (Ed.). (2008). Qualitative research in the study of leadership. Emerald group publishing.

Kondracki, N. L., Wellman, N. S., \& Amundson, D. R. (2002). Content analysis: Review of methods and their applications in nutrition education. Journal of nutrition education and behavior, 34(4), 224-230.

Krippendorff, K. (2012). Content analysis: An introduction to its methodology. Sage publications. Kuckartz, U. (2014). Qualitative text analysis: A guide to methods, practice and using software. Sage.

Leu, T. C., Eriksson, M., \& Müller, D. K. (2018). More than just a job: exploring the meanings of tourism work among Indigenous Sámi tourist entrepreneurs. Journal of Sustainable Tourism, 26(8), 1468-1482.

Moldavska, A., \& Welo, T. (2017). The concept of sustainable manufacturing and its definitions: A content-analysis based literature review. Journal of Cleaner Production, 166, 744-755.

Moleong, Lexy J. (2011). Metode Penelitian Kualitatif, Edisi Revisi. Bandung: PT. Remaja Rosdakarya.

Moretti, F., van Vliet, L., Bensing, J., Deledda, G., Mazzi, M., Rimondini, M. \& Fletcher, I. (2011). A standardized approach to qualitative content analysis of focus group discussions from different countries. Patient education and counseling, 82(3), 420-428.

Mottiar, Z., Boluk, K., \& Kline, C. (2018). The roles of social entrepreneurs in rural destination development. Annals of Tourism Research, 68, 77-88.

Ningdong, Y., \& Mingqing, L. (2017). Community entrepreneurship, female elite and cultural inheritance Mosuo women's empowerment and the hand-weaving factory. In Tourism and Ethnodevelopment, 188-199. New York: Routledge.

Noruzi, M., Westover, J., Rahimi, G. (2010). An Exploration of Social Entrepreneusrhip in the Entrepreneurship Era. Asian Social Science, 6 (6), 3-10.

Patra, S.and S. Nath. (2014). Social Transformation through Social Entrepreneusrhip: An Exploratory Study. The IUP Journal of Entrepreneurship Development, 11 (1), 7-17.

Patton, M. Q. (2002). Qualitative research and evaluation methods (3rd ed.). Thousand Oaks, CA: Sage Publications.

Puspitasari, Cahyani. (2018). Menjadi Sociopreneur Muda: Potret dan Dinamika Momsociopreneur 'Sanggar ASI'. Jurnal Studi Pemuda, 7 (2), 76-89.

Singh, A. (2016). The process of social value creation: A multiple-case study on social entrepreneurship in India. Springer.

Sloan, P., Legrand, W., Simons-Kaufmann, C. (2014). A Survey of Social Entrepreneurial Community-Based Hospitality and Tourism Initiatives in Developing Economies. Worldwide Hospitality and Tourism Themes, 6 (1), 51-61.

Subadra, IN., Nadra, N. M. (2006). Dampak Ekonomi, Sosial Budaya, dan Lingkungan Pengembangan Desa Wisata di Jatiluwih-Tabanan. Jurnal Manajemen Pariwisata, 5 (1), 46-64.

Subarkah, A. R., Rachman, J. B., \& Akim, A. (2019). Wisata Halal Untuk Tujuan Pembangunan Berkelanjutan. Konferensi Nasional Ilmu Administrasi, 3(1).

Suyatna, H., Nurhasanah, Y. (2017). Sociopreneurship Sebagai Tren Karir Anak Muda. Jurnal Studi Pemuda, 6 (1), 527-37.

UNICEF. (2007). Adolescents and Civil Engagement: Social Entrepreneurship and Young People. New York: UNICEF.

Valdivia, Carmen Paola Sota. (2018). The Role of Social Entrepreneurs in Community-Based Rural Tourism in Developing Countries. Graduate Thesis, University of Ljubljana. 
Vargas-Sánchez, Alfonso \& Moral-Moral, María. (2019). Halal Tourism: State of The Art. Tourism Review.

Wibowo, H., Nulhakim, S. A. (2015). Kewirausahaan Sosial Merevolusi Pola Pikir dan Menginisiasi Mitra Pembangunan Kontemporer. Bandung: UNPAD Press.

WTO. (2004). Indicators of Sustainable Development for Tourism Destination: A Guidebook. Madrid: World Tourism Organisation. 